\title{
STRUCTURE AND DIVERSITY OF THE THREE PLANT ASSOCIATIONS IN THE SAN JUAN RIVER DELTA, CHOCÓ, COLOMBIA ${ }^{1}$
}

\author{
Esteban Alvarez-Dávila², Gabriel Camilo Jaramillo-Giraldo², Carlos Cesar Cogollo-Rivera², Hugo Martínez- \\ Higuera $^{3}$, Edward Rojas ${ }^{3}$ and Fernando Fernández-Méndez ${ }^{4 *}$

\footnotetext{
${ }^{1}$ Received on 09.06.2015 accepted for publication on 01.07.2016.

${ }^{2}$ Fundación Con Vida, Medellín, Antioquia - Colombia. E-mail: <esalvarez3000@gmail.com>,<camilojotage@yahoo.com> and < carlos.cogollo.rivera@gmail.com>.

${ }^{3}$ Centro Forestal Tropical Bajo Calima, Universidad del Tolima, Buenaventura, Valle del Cauca - Colombia. E-mail:

$<$ hmartinezh@ut.edu.co $>$ and <edwrovi@hotmail.com>.

${ }^{4}$ Grupo de Investigación en Biodiversidad y Dinámica de Ecosistemas, Universidad del Tolima, Ibagué, Tolima - Colombia. E-mail:<fmendez@ut.edu.co>.

*Corresponding author.
}

\begin{abstract}
The forests of the Pacific Coasts of Chocó are timber suppliers for Colombia. The floodable plant associations have been poorly investigated. To contribute with ecological basis for their management, the aim of this study was to learn about the differences between the forests of three physiographies and how the flood level explains them, comparing these forests with other of the neotropic. Three parcels of 0.5 ha were stablished $y$ and individuals with $\mathrm{DBH} \geq 10 \mathrm{~cm}$ were measured. The most common species is Oenocarpus bataua in well drained zones and Campnosperma panamensis in permanently flooded or swamp. The principal components analysis separated the three communities; the first and the second components explained $48 \%$ and $26 \%$ of the total variation, respectively. There is a high species richness and density of small and medium tall trees in the terrace and hill, in contrast with the low richness in the swamp zone with hyperdominance of one species and a bigger basal area. The dominance of species well adapted to stress caused by hydric excess in the swamp evidenced an environmental filter, that determines a composition and structure particular in the swamp. The studied forests have particular characteristics that differentiate them from other forests of low tropical lands, in particular, a high tree density, less species richness and lower mean wood density compared with Amazonia forests.
\end{abstract}

Keywords: Forests structure; Flooding; Environmental filter.

\section{ESTRUTURA E DIVERSIDADE DE TRÊS ASSOCIAÇÕES VEGETAIS NO DELTA DO RIO SAN JUAN, CHOCO, COLÔMBIA}

RESUMO - Associações de plantas de várzea não tem sido foco da pesquisa. Para contribuir com as bases ecológicas para manejo, objetivou-se conhecer as diferenças entre florestas de três fisiografias e como o nível de inundação explica sua ocorrência, comparando-as com outras florestas neotropicais. Foram estabelecidas três parcelas de 0,5 ha e foram medidos os indivíduos com DAP $\geq 10 \mathrm{~cm}$. A espécie mais comum foi Oenocarpus bataua para a área bem drenada e Campnosperma panamensis para a área de pântano. A análise de componentes principais separou as três comunidades, o primeiro componente explicou $48 \%$ da variação total e o segundo $26 \%$. Teve uma grande riqueza de espécies, assim como também uma alta densidade de árvores pequenas e medianas no terraço e colina, contrastando com a baixa riqueza na área do pântano com hiper dominância de uma espécie e maior área basal. A dominância de espécies bem adaptadas ao excesso hídrico no pântano mostrou um filtro ambiental que determina a composição e estrutura particular do pântano. As florestas estudadas têm caraterísticas particulares diferentes de outras florestas tropicais de terra baixa; particularmente, uma alta densidade de árvores, menor riqueza de espécies e menor densidade média da madeira do que florestas da Amazônia.

Palavras-chave: Estrutura da floresta; Inundações; Filtro ambiental. 


\section{INTRODUCTION}

The biogeographic Choco in Colombia contains the rainiest forests in the planet, with sites with precipitations higher than 10,000 mm/year (HIJMANS et al., 2005). Is a region recognized because of its high floristic richness and a conservations hotspot (GENTRY, 1982; GALEANOetal., 1998; MYERS etal., 2000; RANGEL, 2004). Despite its physiographic diversity, the studies of plant diversity in the Colombian Chocó have been focused to forests in solid ground (GARCÍA et al., 2002; MOSQUERA et al., 2007; QUINTO; MORENO, 2014).

The abiotic factor determine the communities configuration at a local scale, creating assembling patterns according the gradient of available or limiting resources (TILMAN; PACALA, 1993). These conditions are known as niches, showing functional complementarity between species that share a niche (FINEGAN et al., 2015). The niche models include specialization to abiotic conditions and predict that similar floristically parcels share soil, humidity or temperature conditions (STEVENSON; RODRIGUEZ, 2008). For various communities' configurations of the west Amazonia, it has been shown that floristic similarities obey to abiotic factors (TUOMISTO et al. 1995).

The plant communities existent in the floodable areas of the biogeographical Choco have not been studied yet (DEL VALLE, 2000). Where special soil and resources conditions generate dominance of some species more adapted to periodic flooding conditions. It is very important to investigate this to generate forest management and conservation measures, and also for understanding and modelling the response of these communities to the climate change, in particular to the sea level rise that is expected in the coming decades. Only some general dominance patterns have been described denominating these forests as guandal; mixed guandal and cuangarial, dominated by the cuángare (Otoba gracilipes); sajál: characterized by the sajo (Camnosperma panamensis); and naidizal, dominated by the naidí palm (Euterpe oleracea), determined by a waterlogging ascending order (DEL VALLE, 2000).

In this study, the information regarding floristic composition, diversity and structure of the low San Juan River forests is presented, in three physiographic units: hill, terrace and swamp. The aim was to answer three questions: 1) Which are the differences among the forests in the three physiographic units contrasting the San Juan river delta? 2) In what way does the flooding level explain these differences? and 3) How are these forests similar to others in the neotropic? Contributing to the knowledge to these patterns in a local scale, generates useful information for the good management of these forests that are widely used as timber source for the Colombian commerce.

\section{MATERIALS AND METHODS}

The San Juan river delta is located in the Colombian pacific coast between $\left(4^{\circ} 13^{\prime} \mathrm{N} ; 7^{\circ} 11^{\prime} \mathrm{W}\right)$ and $\left(4^{\circ} 23^{\prime} \mathrm{N}\right.$; $77^{\circ} 23^{\prime} \mathrm{W}$ y $\left.4^{\circ} 04^{\prime} \mathrm{N} ; 7^{\circ} 28^{\prime} \mathrm{W}\right)$ coordinates, conforming the alluvial cone of various river branches. Mean temperature $28^{\circ} \mathrm{C}$, relative humidity higher that $90 \%$ and mean year precipitation of $7600 \mathrm{~mm}$ (FABERLAGENDOEN; GENTRY, 1991; HIJMANS et al., 2005). The life zone is a transition from a tropical very humid forest (bmh-T) to a premontane pluvial forest (bp-Pm) (HOLDRIDGE, 1971; IGAC, 1988).

These forests are located in the San Juan river alluvial plain with dissected terraces, hills and swampy floodable zones that belong to the pacific physiographic region, subregion $\mathrm{RPb}$ (Pacific Plain) formed as a fluviodeltaic plain (IGAC, 1988) with alluvial and lacustrine soils with low to medium organic contents (1.0-1.5\% a $1.5-2.5 \%$ organic carbon). Extremely acid soils due to the abundant pluviosity, lixiviation and high phreatic level, with a AI saturation higher than $60 \%$ and low available $\mathrm{P}(<30 \mathrm{ppm})$. Composed by ALFAPQ (Altereds, Feldspars, Amphiboles, Pyroxenes and Quartzes) sands and KMI clays (Kaolinite, Mica and Integrates) (IGAC, 1982).

In the Cuángare foundation biological station in the low San Juan, contrasting physiographic units were determined: 1) Hill: low hills well drained with and altitude of 30-50 masl and superior tertiary geological origin, free of flooding effects; 2) Terrace: in the superior tertiary alluvial plain, with altitude of 10-17 masl, moderately drained and undulated topography, with sporadic floodings during river risings related to tides and 3 ) swamp: permanently flooded plain.

In each physiographic unit a parcel of $20 \times 250 \mathrm{~m}$ was stablished, divided in five quadrants of $20 \times 50 \mathrm{~m}$, subdivided in 10x10 m quadrants where all individuals with $\mathrm{DBH} \geq 10 \mathrm{~cm}$ were measured. Botanical samples were collected and determined in the JAUM and HUA herbariums from Medellín and COL from Bogotá. The 
families are listed under the APG III (2009) classification and their scientific names were consulted in IPNI, W3 tropics and The Plant List.

The list of species, genera and families for each parcel was made; the importance value index (IVI) was calculated: in order to evaluate the differences in floristic composition a correspondence analysis DCA was performed in the three physiographies. For the structural analysis, it was calculated, per subparcel 20x50 m (0.1) ha, the following variables for each physiography: number of species (ne), total number of individuals (ni), number of individuals in five diametric classes as: DBH 10$20 \mathrm{~cm}$ (rl), 20-30 cm (r2), 30-40 cm (r3), 40-50 cm (r4), $>50 \mathrm{~cm}(\mathrm{r} 5)$, basal area $\mathrm{m}^{2}(\mathrm{ab})$, wood density $\left(\mathrm{g} / \mathrm{cm}^{3}\right)$ (WD), dominant height of the five most tall trees (m) (ad) and maximum diameter $(\mathrm{cm})$ Dmax. The density of the WD wood was extracted de from the Global Wood Density database (GWD) (ZANNE et al., 2009). For the most known species the specific WD value was assigned; in the case of non-common species the mean WD at the genus level was used, and for the genus not registered in the GWD the family WD mean value was used.

With all the structural and richness variables, it was evaluated if differences existed among the three physiographies, by means of Kruskall-Wallis (K-W) non parametric ANOVA test, and a least significant difference (LSD) multiple ranges test. By means of a Principal Component Analysis (PCA) and Ward method grouping analysis, the parcels that shared a similar combination of structural characteristics were identified; the analyses were done with PAST software (HAMMER et al., 2001). To compare this study with others in the neotropics, a table was made with data of the reviewed literature that was analyzed and discussed (Table 1).

\section{RESULTS}

A total of 173 species (118 genera and 50 families) were found, from which 161 trees, 10 palms and 2 lianas were present (the complete list of species can be obtained from the first author of this study). The major taxa richness was found in the hill, followed by the terrace, and the less richness was that of swamp. The richness of species, genera and families is similar for the hill (100-79-41) and terrace (93-77-40) with non-significant differences in the number of species (Figure 1), but the mixture quotient (number of species/number of individuals) is higher in the hill (0.37) that in the terrace
(0.28). In the swamp a richness inferior to nine species, eight genera and six families was found and there are significant differences among the species richness in the swamp and the other two landscapes (Figure 1).

The species abundance shows a more homogeneous composition in the swamp forest, underscoring the low species richness and the presence of a hyperdominant species: Campnosperma panamensis. There is low dominance in the hill and terrace, with an IVI of 7.2 and 4.5, respectively, for the most dominant species (Oenocarpus bataua) in both cases; in the swamp, C. panamensis, is the most important with an IVI of $65 \%$. This species is not one of the 10 most dominant in the hill and terrace, on the contrary, is rare. The 10 species with a higher IVI represent the $16.8 \%, 34.8 \%$ and $100 \%$ in the hill, terrace and swamp, respectively, indicating an increment in dominancy at higher flooding level (Figure 2).

Only one species, dominant in the hill and terrace was found: Tapirira guianensis, and there are no common dominant species in the swamp with respect to the hill and terrace (Figure 2). The quadrant correspondence analysis of 0.1 ha, shows the separation or each landscape according to the floristic composition (Figure 3 ).

The totality of individuals was $1331,83 \%$ trees, $16 \%$ palms and $1 \%$ lianas. The number of trees per hectare was 766 in the hill, 986 terrace and 910 swamp. From the 11 structural variables for the 1 ha quadrants, significant differences were found for the number of species (ne), number of individuals in superior diametrical classes ( $\mathrm{DBH}>20)$, basal area $(\mathrm{ab})$ and wood density (Figure 1). For the rest of the variables the differences were not significant.

The structural typification analysis shows that the first three components of the PCA explain the $86.7 \%$ of the variation in the forests' structure (Figure 4A). In particular, the first component with $46.5 \%$, clearly separates the 0.1 ha quadrants of the swamp forest from the rest of quadrants. Among terrace and hill it is observed a similar but less important effect. The first component is highly correlated with the flooding level $(\mathrm{R}$ Pearson $=0.89 ; \mathrm{p}=0.000)$ evidencing that the forests are structured along a gradient, with the swamp forest having a low species richness, low wood density and a high number of individuals with $\mathrm{DBH} \geq 40 \mathrm{~cm}$ in a clearly and structuraly differentiated group, grouping the terrace and hill parcels (Figure 4B)

Revista Árvore, Viçosa-MG, v.40, n.5, p.833-843, 2016

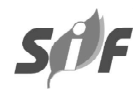



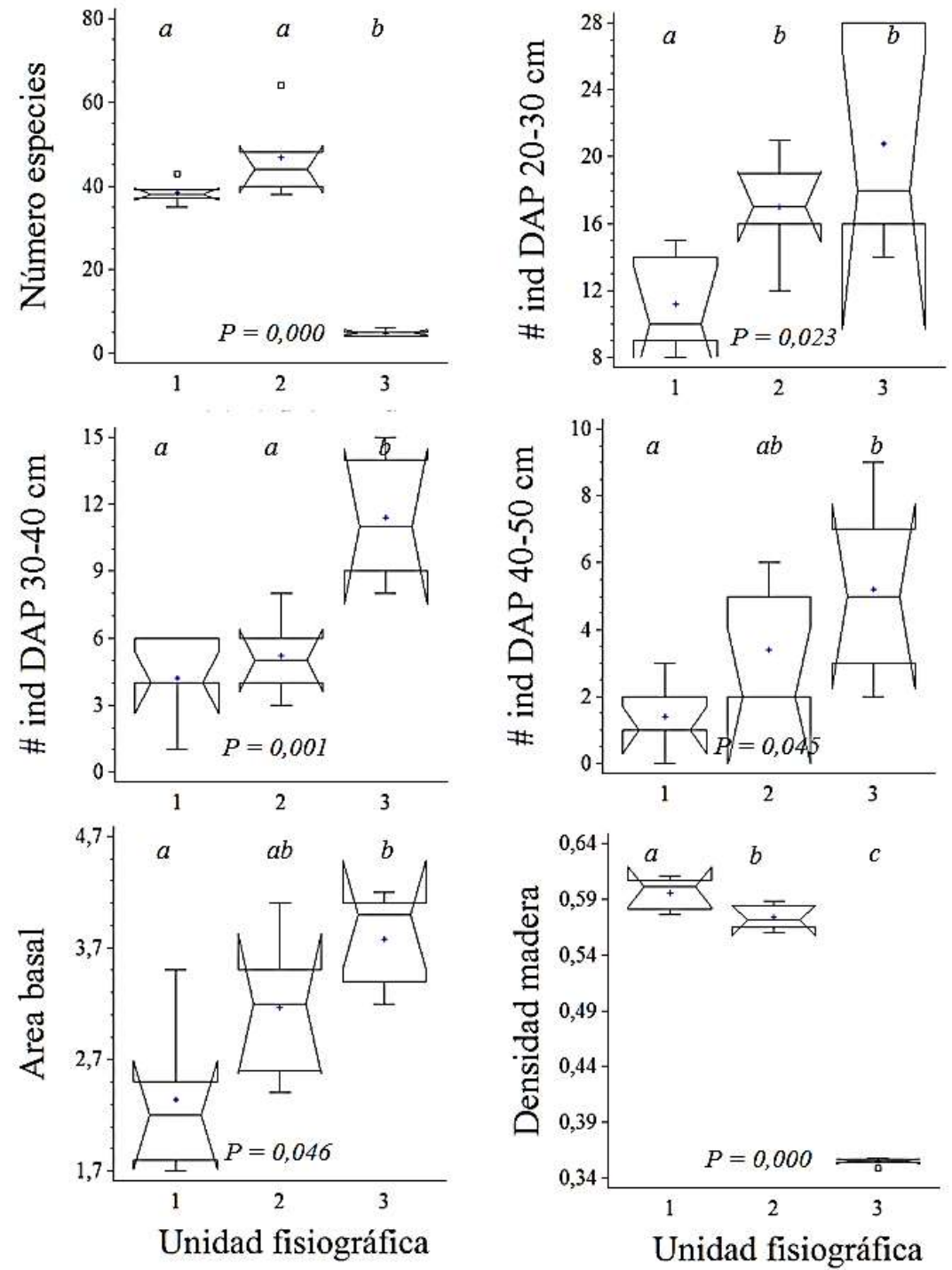

Figure 1 - Kruskal-Wallis analysis with a 95\% confidence to compare structural variables in the three physiographies of San Juan river Delta, Chocó, Colombia. Physiographic Unit $1=$ hill, $2=$ terrace and $3=$ swamp.

Figura 1 - Análise de Kruskal-Wallis, com 95\% de confiança para comparar variáveis estruturais em três fisiografias do Delta do rio San Juan. Choco, Colômbia. Unidade fisiográfica: $1=$ Colina, $2=$ Terraço, $3=$ Pântano.

\section{DISCUSSION}

\subsection{Hill and Terrace}

Contrary to the species richness for the 0.5 ha units, the mean per 0.1 ha quadrant is superior in the terrace than in the hills, which can be related to the fact that there is a higher diversity of habitats in the terraces as product of sporadic flooding and the relief that generates microsites with better draining than others. The hyperdominance of sajo (Campnosperma panamensis) in the swamp agrees with other reports on waterlogging areas in tropical regions (DUIVENVOORDEN, 1996; GRAUEL, 2004). The number of trees per hectare ( 766 for the hill, 986 terrace and 910 swamp), represent a higher value than the reported previously for other tropical forests (Table 1). The forest structure of the hill and terrace of the San Juan river delta have similar characteristics 


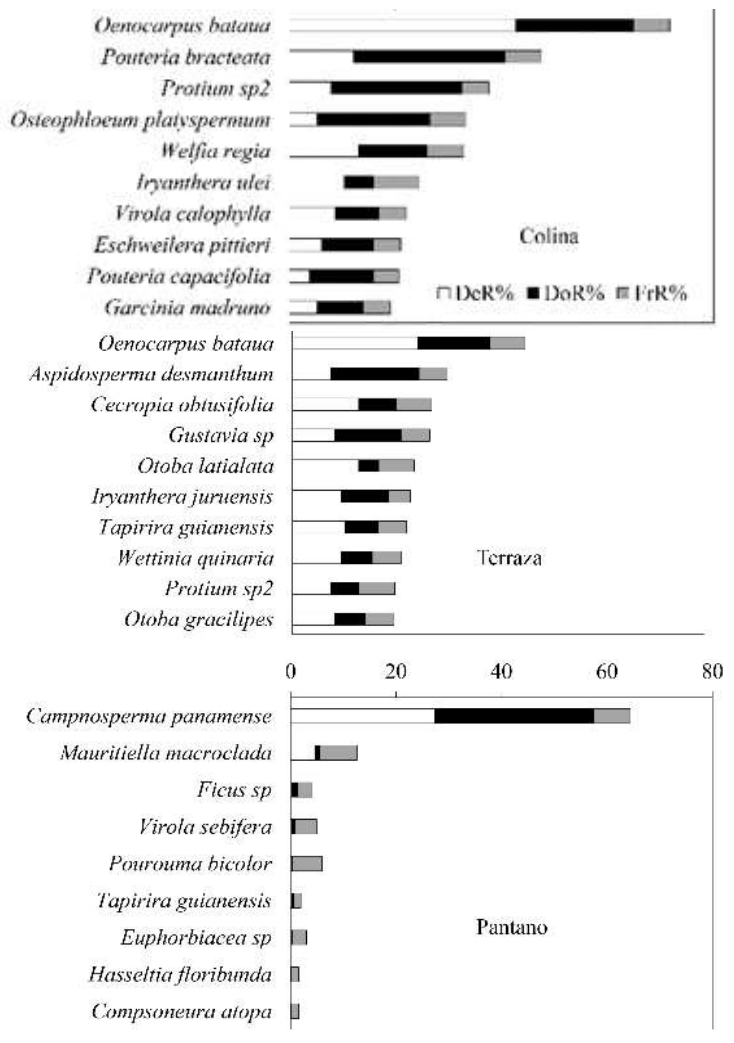

Figure 2 - Importance value index (IVI) for the dominant species in the three physiographies in the San Juan river delta, Chocó, Colombia.

Figura 2-Índice de Valor de Importância para as espécies dominantes em três fisiografias do delta do Rio San Juan. Choco, Colômbia.

to what has been reported by other studies on Chocó forests (Table 1). Nevertheless, the literature review showed the few existing knowledge regarding the ecology of pluvial forests in the north of the South American pacific, and that is why references to other similar forests in the Amazonia and Asian southeast were included.

It is noteworthy the few representation of big trees, with just 180 individuals with DBH $20 \mathrm{~cm}$ and 68 with $\mathrm{DBH}>30$. This numbers can be compared with those of other Neotropical sites, using the index developed by Uhl: Murphy (1981), suggested by Faber-Lagendoen; Gentry (1991). This index determines the relation between the number of individuals with $\mathrm{DBH}$ between 10-20 $\mathrm{cm}$ divided by the number of individuals with $\mathrm{DBH}>20$ $\mathrm{cm}$, where the high values indicate that the majority of trees are found in the least size classes Uhl; Murphy

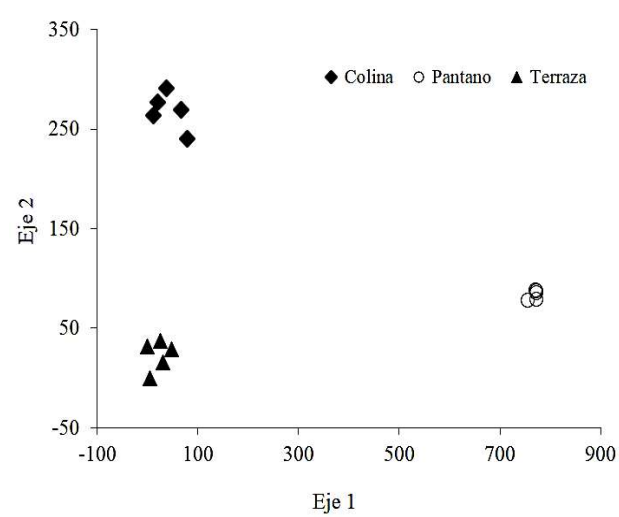

Figure 3 - DCA for the species composition in the three physiographies of San Juan river delta, Chocó, Colombia.

Figura 3-DCA para composição de espécies em três fisiografias do Delta do rio San Juan. Choco, Colômbia.

(1981) report the higher index value of 3.4 in two sites with soils poor in nutrients close to Belem, Brazil and San Carlos, Venezuela. In Borneo, it has been reported, for a low land forest in poor soils, an index of 3.46 (PROCTOR et al., 1983). In comparison, the hill and terrace parcels index value in the present study was 3.3 and 2.7; the hill value is similar to the one of forests studied in a nearby site by Faber-Lagendoen; Gentry (1991) with values between 3.4 and 3.7

The low number of big trees in the San Juan river delta is also evident from the comparisons of trees with DAP $\geq 30$ in six sites of 1 ha studied by Gentry (1988) in the Amazonia. The minimal number of trees with $\mathrm{DBH}>30 \mathrm{~cm}$ reported by Gentry (1988) was 80 , a medium value compared with the one found in this study in the San Juan River delta, with a range between 68 and 98. Faber-Lagendoen; Gentry (1991) found 74 to 83 individuals with $\mathrm{DBH} \geq 30 \mathrm{~cm}$. The low density of big trees in our site agrees with other reports for the same region, in concordance with a forest inventory made by Smurfit Cartón de Colombia, that covered a total area of $24 \mathrm{ha}$, in which only 8 individuals/ha $(0.56 \%)$ with $\mathrm{DBH} \geq 82 \mathrm{~cm}$ and only 16 with a $\mathrm{DBH} \geq 62 \mathrm{~cm}$ were reported (Faber-Lagendoen; Gentry 1991). In present study case, we did not find trees with values higher than $80 \mathrm{~cm}$ and just one higher than $62 \mathrm{~cm}$, also an inferior value of that reported by Faber-Lagendoen; Gentry (1991).

In the terrace $90 \%$ of the trees with $\mathrm{DBH}<30 \mathrm{~cm}$ were found and in solid ground $91 \%$, and the number of individuals and basal area showed no significant

Revista Árvore, Viçosa-MG, v.40, n.5, p.833-843, 2016 

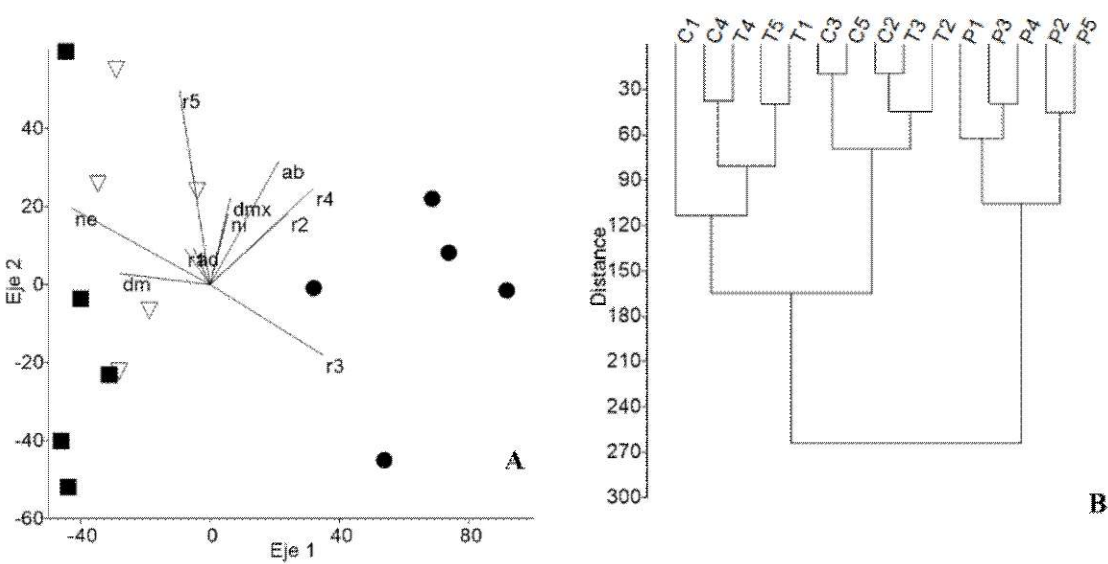

Figure 4 - Structural types of three physiographies of San Juan river delta, Chocó, Colombia. (DBH $\geq 10 \mathrm{~cm})$. A. Principal components analysis. B. Grouping analysis. Squares $=$ hill, Triangles $=$ terrace; Circles $=$ swamp.

Figura 4 - Tipos estruturais de três fisiografias do Delta do rio San Juan. Choco, Colômbia (DAP $\geq 10 \mathrm{~cm})$. A. Análise de componentes principais. B. Análise de agrupamento. Quadrado = Colina; triangulo = Terraço; Círculos = Pântano.

differences among them; the same happens with the structural typification by means of PCA (Figure 4), that groups some of the solid ground subparcels with those of the terrace, which are characterized by having a low number of total individuals and a low number of trees with values higher than $40 \mathrm{~cm}$ at $\mathrm{DBH}$.

The species richness in the hill and terrace forests, within the range of $81-152$ species per 0.5 ha reported in other solid ground forests in Chocó, is lower than the mean for Amazon forests, but higher than those of African and Asiatic forests (Table 1). The most abundant species for both parcels is the palm O. bataua, a recognized solid ground generalist in the north Amazon (DUQUE; CÁRDENAS, 2003) and in some places in Chocó (GENTRY, 1986; FABER-LANGENDOEN; GENTRY; 1991) and other sites of the neotropic like mid Magdalena in Colombia (YEPES-QUINTERO et al., 2007) and the Darien region (ZULUAGA, 1987).

Besides palms, in general for both physiographies, it is noticed a high density of arboreal individuals per hectare; higher than the mean reported for Amazon, Asian and African forests, as well as a less tree size mean (HUNTINGFORD et al., 2013) (Table1).

\subsection{The Swamp Forest}

Regionally known as "sajal" is in constrast with the other physiographies because of the few species, genera and therefore families with a mixture quotient of 0.02 species/individual. The floristic differences with the hill and terrace is highlighted in the structural typification graphic (Figure 3 ) where the number of species (ne) vector is determinant in the forest type separation. Additionally, el sajal, has a high number of trees with intermediate sizes (DBH 20-30 cm), and high basal area, compared to the other two parcels. The Uhl index; Murphy (1981) was of 1.4 indicating a higher proportion of big trees in contrast with the hill and terrace.

In this parcel the dominance and abundance belongs almost exclusively ( $92 \%$ and $82 \%$, respectively) to $C$. panamensis. The DCA analysis (Figure 3 ) clearly separates the sajal composition from that of the hill and terrace. These differences can be explained by this parcel flooding level, which determines the development of sajo dominant populations ( $C$ panamensis) a swamp riparian tree, endemic to the biogeographical Chocó(GENTRY, 1993) and of Mauritiella macroclada a gregarious palm that although is comprised of populations of many individuals, are not usually dominant, but rather associated to other dominant species (GALEANO, 1991). Both sajo and M. macroclada are adapted to the extreme flooding conditions (DEL VALLE, 2000). In terms of species richness, the tree density and basal area, of this forest is similar to the "sajo forest" of the Patía river delta in Chocó, but different to other ("Cuangarial" y "Guandal") studied by Del Valle (1996) (Table 1). When it is compared with the 
Table 1 - Diversity and structure studies made in the neotropical region for plants with DBH $\geq 10 \mathrm{~cm}$ (Flooded Forests *). $\mathrm{a}=16$ parcels mean of Van Gemerden et al. (2013); $\mathrm{b}=$ Figures and tables mean of Gentry (1988): $\mathrm{c}=$ mean with respect to the real parcel size: $d=0.1$ ha parcels mean; Nsp = Number of species per hectare; Nind $=$ Number of individuals per hectare; Basal A. = Basal area; WD prom = mean wood density: Tree Basal A. mean $=$ mean basal área per tree. Sources: 1 = Galeano (2001), 2 = Faber-Langendoen y Gentry (1991), $3=$ This study, 4 = García et al. (2002), $5=$ Del Valle (2000), $6=$ Lewis et al. (2013), 7 = Londoño (2011), 8 = Urrego-Giraldo (1997), 9 = Koehler et al. (2002), 10 = Carvalho et al. (2006).

Tabla 1 - Estudos de diversidade e estrutura realizadas na região Neotropical para plantas com DAP $\geq 10 \mathrm{~cm}$ (florestas inundadas *). $a$ = média de 16 parcelas de Van Gemerden et al. (2013); b = media de figuras e tabelas de Gentry (1988); $c$ = média com respeito ao tamanho real da parcela; $d=$ media a partir de parcelas de 0,1 ha; Nsp= número de espécies por hectare; Nind = número de individuos por hectare; A.basal = Area basal; DM prom = densidade de madeira média; Abasal árbol prom = área basal media por árvore. Fontes: $1=$ Galeano (2001), 2 = Faber-Langendoen y Gentry (1991), 3 = Esse estudo, 4 = García et al. (2002), 5 = Del Valle (2000), $6=$ Lewis et al. (2013), $7=$ Londoño (2011), $8=$ Urrego-Giraldo (1997), $9=$ Koehler et al. (2002), $10=$ Carvalho et al. (2006).

\begin{tabular}{|c|c|c|c|c|c|c|c|c|c|c|}
\hline Region & Site & Site & $\begin{array}{l}\text { Size } \\
\text { (ha) }\end{array}$ & $\begin{array}{c}\text { Nsp } \\
\text { ha }\end{array}$ & $\begin{array}{c}\text { Nsp 0,5 } \\
\text { ha }\end{array}$ & $\begin{array}{c}\text { Nind } \\
\text { ha }\end{array}$ & $\begin{array}{c}\text { Basal A } \\
\mathrm{m}^{2} / \mathrm{ha}\end{array}$ & $\begin{array}{c}\text { Mean WD } \\
\mathrm{pgr} / \mathrm{cc}\end{array}$ & $\begin{array}{c}\text { Tree Basal A. } \\
\text { mean m }{ }^{2}\end{array}$ & Source \\
\hline Chocó & Tribugá Gulf & Solid ground & 1.0 & 127 & 81 & 481 & 26.5 & 0.530 & 0.055 & 1 \\
\hline Chocó & Low Calima & Solid ground & 1.0 & 258 & 152 & 664 & 25.0 & 0.595 & 0.038 & 2 \\
\hline Chocó & Low San Juan & Terrace & 0.5 & & 95 & 976 & 31.6 & 0.588 & 0.032 & 3 \\
\hline Chocó & Low San Juan & Solid ground & 0.5 & & 101 & 760 & 23.2 & 0.605 & 0.031 & 3 \\
\hline Chocó & Low San Juan & *Swamp (sajal) & 0.5 & & 9 & 910 & 37.8 & 0.355 & 0.042 & 3 \\
\hline Chocó & Low San Juan & Terrace+TF & 1.0 & 257 & & 868 & 27.4 & 0.596 & 0.032 & 3 \\
\hline Chocó & Quibdó & Solid ground & 1.0 & 219 & 140 & 709 & 28.1 & 0.639 & 0.040 & 4 \\
\hline Chocó & Quibdó & Solid ground & 1.0 & 177 & 121 & 638 & 24.3 & 0.622 & 0.038 & 4 \\
\hline Chocó & Low Patía & *Swamp (sajal) & 1.0 & 9 & 9 & 898 & 33.8 & 0.362 & 0.038 & 5 \\
\hline Chocó & Low Patía & *Swamp (guandal) & 1.0 & 37 & 30 & 639 & 17.9 & 0.480 & 0.028 & 5 \\
\hline Chocó & Low Patía & *Swamp (cuangarial) & 1.0 & 29 & 24 & 709 & 32.0 & 0.420 & 0.045 & 5 \\
\hline África & Africa & Solid ground & 1.0 & $127 \mathbf{a}$ & $75 b$ & 425 & 31.5 & 0.650 & 0.074 & 6 \\
\hline Asia & Asia & Solid ground & 1.0 & $152 \mathbf{b}$ & $94 b$ & 602 & 37.1 & 0.600 & 0.062 & 6 \\
\hline Amazonia & Amazonia & Solid ground & 1.0 & $204 \mathbf{b}$ & $138 b$ & 597 & 29.0 & 0.660 & 0.049 & 6 \\
\hline Amazonia & Amazonia Col & *sporadically flooded & 1.0 & 141 & 89 & 667 & 20.6 & 0.665 & 0.031 & 7 \\
\hline Amazonia & Amazonia Col & Solid ground & 1.0 & 228 & 155 & 865 & 30.5 & 0.708 & 0.035 & 7 \\
\hline Amazonia & Amazonia Col & *Swamp & 1,0 & 75 & 41 & 1074 & 32,7 & 0,633 & 0,030 & 8 \\
\hline Brazil SE & Paraná & *Periodic flooding & 0.4 & & $78 c$ & 1085 & 40.1 & 0.618 & 0.037 & 9 \\
\hline Brazil SE & Paraná & *Periodic flooding & 0.3 & & $26 c$ & 1384 & 48.7 & 0.623 & 0.035 & 9 \\
\hline Brazil SE & Río de Janeiro & *Periodic flooding & 0.7 & & $31 \mathrm{c}$ & 873 & 36.6 & 0.646 & 0.042 & 10 \\
\hline
\end{tabular}

swamp Amazon forest, it is observed a similitude with in the high stem density and basal area, but the species richness is significantly lower (Table 1). An important characteristic is the wood low mean density in the swamp, in comparison with the hill and terrace forests, which can also be explained because of the dominance of C. panamensis. A similar characteristic is found in other floodable forests in Chocó, with wood density equally low $(<0.48 \mathrm{gr} / \mathrm{cc})$, which is contrast with the high density of the floodable Amazon forests $\left(>0.618 \mathrm{gr} / \mathrm{cm}^{3}\right)$ (Table 1). In the swamp floodable Amazon forests is common to find a higher species richness, with the abundant presence of some species that have a high wood density $\left(>0.8 \mathrm{gr} / \mathrm{cm}^{3}\right)$, like Brownea coccinea subsp. capitella y Zigya latifolia (LONDOÑO, 2011).

\subsection{Flooding as a determinant of forest structure.}

Numerous studies show that the flooding cycles determine in a significant way, the structural and floristic variation in the low neotropical lands (BALSLEV et al., 1987; CONDIT etal., 1996; DUIVENVOORDEN, 1996; STEVENSON et al., 1999; PITMAN et al., 2014) generally demonstrating that the forests with low diversity are associated with frequent or permanent floodings (PETERS et al., 1989; HART, 1990). Duivenvoorden (1996) found that in forests near to Caquetá river in the Colombian Amazon, the number of trees species diminishes to the extent that the drainage is more limiting: higher in the landscapes without this limitation, intermediate in the landscapes with moderately well

Revista Árvore, Viçosa-MG, v.40, n.5, p.833-843, 2016 
drained soils and low when the soils are badly drained, in agreement to what URREGO-GIRALDO (1997) found in the same region.

During the floodings, oxygen depletion in the rhizosphere generates a reduction in the stomatal conductance, low photosynthesis rates, hormonal imbalance, water and nutrient deficient absorption, affecting the growth, development and survival of species that are not adapted to these conditions (PARENT et al., 2008). In this sense, the low species richness in the tropical swamp forests is generally due to the inability of solid ground species to face the stress conditions that result from the permanent floodings (BLACK et al., 1950; CAMPBELL et al., 1986; 1992; DUIVENVOORDEN 1996; LÓPEZ; KURSAR et al. 2003).

The environmental filter that flooding represents for many tropical forest species, determinant of the associated trees community composition, has been recognized since several decades ago (HAWES et al., 2012). Recently, Fortunel et al. (2014) demonstrated that the filter generated by the flooding also determines the species and functional composition in a large scale in the low land forests in the Amazon, where the solid ground species present a greater wood density than the floodable forest, as a generalization similar to the one shown in the present study, among other key functional features of the leaves, confirming the importance of the niche related processes. Nevertheless, the findings of Fortunel et al. (2014) and Baraloto et al. (2011) in relation to the higher number of stem and basal area in the solid ground forests do not agree with the results presented here for the San Juan river delta, where the flooding intensity is correlated with a higher tree density and basal area.

In spite of the evident permanent flooding effect in the species richness and composition in the tropical forests, some studies show that forests with sporadic flooding may harbor a high species richness, but lower than those of solid ground. Londoño (2011) reported that number of species of trees with $\mathrm{DBH} \geq 10 \mathrm{~cm}$ in 1 ha parcels in the Amazonia, varied among 94300 species for solid ground forests and between 36165 species for várzea forests. In the várzea forests, also in the Amazon, another study reported a high vascular plants richness, with close to 511 species in a 1.8 ha parcel (LONDOÑO; ALVAREZ, 1997).

\section{CONCLUSIONS}

There is a high species richness, and in the same way a high density of small and intermediate size trees in the terrace and the hill, in contrast to the low richness in the swamp zone with hyperdominance of one species and a higher basal area.

The dominance of species well adapted to hydric stress in the swamp shows a strong environmental filter comparable to the floodable zones in the Amazonia, which determines a particular composition and structure in the swamp.

The forests studied here have particular characteristics that differentiate them of other low land tropical forests; in particular, a high tree density, less species richness and less mean wood density than the Amazon forests.

\section{AKNOWLEDGEMENTS}

Joaquín Antonio Uribe botanical garden foundation (JAUM): permanent parcels network for the monitoring of the Colombian forests and climate change (COLTREE), MADECEN for the logistics financing. Colciencias - Medellín Botanical Garden (JBMED) agreement. Contract No 392-2012 (Forest Dynamics in Colombia) and JBMED - Leeds University agreement, supported by the Moore Foundation. To the low Calima river forestry center of Universidad del Tolima and to the afrodescendant communities for allowing this study to be made in their collective territory and for their support in the field tasks.

\section{REFERENCIAS}

ANGIOSPERM PHYLOGENY GROUP III - APG III. An update of the Angiosperm Phyogeny Group classification for the orders and families of flowering plants APG III. Botanical Journal of the Linnean Society. v.161, n.2, p.105-121, 2009.

BALSLEV, H.; LUTEIN, J.; ØLGAARD, B.; HOLMNIELSEN, L.B. Composition and structure of adjacent unflooded and flood plain forest in Amazonian Ecuador. Opera Botanica, v.92, n.1, p.37-57, 1987.

BARALOTO, C.; RABAUD, S.; MOLTO, Q.; BLANC, L.; FORTUNEL, C.; HIERAULT, B.; DAVILA, N.; MESONES, I.; RIOS, M.; 
VALDERRAMA, E.; FINE, P.V.A. Disentangling stand and environmental correlates of aboveground biomass in Amazonian forests. Global Change Biology, v. 17, n.8, p.2677-2688, 2011.

BLACK, G.A.; DOBZHANSKY, T.; PAVAN, C. Some attempts to estimate species diversity and population density of trees in Amazonian forests. Botanical Gazette, v.111, n.4, p.413-425, 1950.

CAMPBELL, D.G.; DALY, D.C.; PRANCE, G.; MACIEL, U.N. Quantitative ecological inventory of terra firme and várzea tropical forest on the Rio Xingu, Brasilian Amazon. Brittonia, v.38, p.369-393, 1986.

CAMPBELL, D.G.; STONE, J.L.; ROSAS, A.JR. A comparison of the phytosociology and dynamics of three (varzea) forests of known ages, Rio Juru, Western Brazilian Amazon. Botanical Journal of the Linnean Society, v.108, p.213-237, 1992.

CARVALHO, F.A.; NASCIMENTO, M.T.; BRAGA, J.M.A.; RODRIGUES, P.J.F.P. Estrutura da comunidade arbórea da Floresta Atlântica de baixada periodicamente inundada na Reserva Biológica de Poço das Antas, Rio de Janeiro, Brasil. Rodriguésia, v.57, p.503-518, 2006.

CONDIT, R.; HUBBELL, S.P.; FOSTER, R.B. Changes in tree species abundance in a Neotropical forest: impact of climate change. Journal of Tropical Ecology, v.12, n.2, p.231-256, 1996.

DEL VALLE, J.I. Consideraciones estructurales de los bosques de guandal del pacifico sur colombiano. Revista Facultad Nacional de Agronomía, v. 53, n.2, p.1011-1042, 2000.

DEL VALLE, J.I. Los bosques de guandal del delta del Río Patía colombiano. Revista de la Academia Colombiana de Ciencias Exactas Físicas y Naturales, v.20, n.78, p.475-489, 1996.

DUIVENVOORDEN, J.F. Patterns of tree species in rain forests of the middle Caquetá area, Colombia, NW Amazonia. Biotropica, v.28, n.2, p.142-158, 1996.

DUQUE, A.; CÁRDENAS, D. Dominancia florística y variabilidad estructural en bosques de Tierra
Firme en el noroccidente de la Amazonía colombiana. Caldasia, v.25, n.1, p.139-152, 2003.

FABER-LANGENDOEN D.; GENTRY, A. The structure and diversity of rain forests at Bajo Calima, Chocó Region, Western Colombia. Biotropica, v.23, n.1, p.2-11, 1991.

FINEGAN, B.; PEÑA-CLAROS, M.; DE OLIVEIRA, A.; ASCARRUNZ, N.; BRET-HARTE, M.S.; CARREÑO-ROCABADO, G.; CASANOVES, F.; DÍAZ, S.; EGUIGUREN VELEPUCHA, P.; FERNANDEZ, F.; LICONA, J.C.; LORENZO, L.; SALGADO-NEGRET, B.; VAZ, M.; POORTER, L. Does functional trait diversity predict aboveground biomass and productivity of tropical forests? Testing three alternative hypotheses. Journal of Ecology, v.103, p.191-201, 2015

FORTUNEL, C.; RUELLE, J.; BEAUCH, J.; FINE, P.V.A.; BARALOTO, C. Wood specific gravity and anatomy of branches and roots in 113 Amazonian rainforest tree species across environmental gradients. New Phytologist, v.202, p.79-94, 2014

GALEANO, G. Las palmas de la región de Araracuara. In: SALDARRIAGA, J.G.; VAN DER HAMMEN, T. (Ed.) Estudios en la Amazonia Colombiana I. Bogotá: Tropenbos-Colombia, 1991. v.1

GALEANO, G.; SUÁREZ, S.; BALSLEV, H. Vascular plant species count in a wet forest in Chocó área on the Pacific coast of Colombia. Biodiversity and Conservation, v.7, p.1563-1575, 1998.

GALEANO, G. Estructura, riqueza y composición de plantas leñosas en el Golfo de Tribugá, Chocó, Colombia. Caldasia, v.23, n.1, p.213-236, 2001

GARCÍA, F.; del PALACIOS, J.C.; RAMOS, Y.A.; MENA, A.; ARROYO, J.E.; GONZÁLEZ, M. Composición, estructura y etnobotánica de un Bosque Pluvial Tropical (bp-T), en Salero,

Chocó. Revista Institucional Universidad Tecnológica del Chocó, v.17, p.3-9, 2002.

GENTRY, A.H. Patterns of Neotropical plant species diversity. Evolutionary Biology, v.15, p.1-84, 1982.

Revista Árvore, Viçosa-MG, v.40, n.5, p.833-843, 2016 
GENTRY, A.H. Species richness and floristic composition of Chocó region plant communities. Caldasia, v. 15, p.71-79. 1986.

GENTRY, A.H. Species richness of upper Amazonia. Proceedings of the National Academy of Sciences, v.85, n.1, p.156-159, 1988.

GENTRY, A.H. A field guide to the families and genera of woody plants of Northwest South America (Colombia, Ecuador, Peru) with supplementary notes on herbaceous taxa. London: The University of Chicago Press, 1993. 895p.

GRAUEL, W.T. Structure, composition, and dynamics of Prioria copaifera-dominated swamp forests in Darien, Panama. In: Ecology and management of wetland forests dominated by Prioria copaifera in Darien, Panama. 2004. (Ph D) - University of Florida, 2004. http://etd.fcla.edu/UF/ UFE0004366/grauel_w.pdf..

HAMMER, Ø.; HARPER, D.A.T.; RYAN, P.D. PAST: Paleontological statistics software package for education and data analysis. Palaeontología Electronica, v.4, n. 1, p.1-9, 2001.

HART, T.B. Monospecific dominance in tropical rain forests. Trends in Ecology and Evolution, v.5, n.1, p.6-11, 1990.

HAWES, J.E.; PERES, C.A.; RILEY, L.B.; HESS, L.L. Landscape-scale variation in structure and biomass of Amazonian seasonally flooded and unflooded forests. Forest Ecology and Management, v.281, p.163-176, 2012.

HIJMANS, R.J.; CAMERON, S.E.; PARRA, J.L.; JONES, P.G.; JARVIS, A. Very high resolution interpolated climate surfaces for global land areas. International Journal of

Climatology, v.25, n.1, p.1965-1978, 2005.

HOLDRIDGE, L.R. Forest environment in tropical life zones: a pilot study. Oxford: Pergamon Press, 1971. 747p.

HUNTINGFORD, C.; ZELAZOWSKI, P.; GALBRAITH, D.; MERCADO, L.M.; SITCH, S.;
FISHER, R.; COX, P.M. Simulated resilience of tropical rainforests to $\mathrm{CO} 2$-induced climate change. Nature Geoscience, v.6, n.4, p.268-273, 2013.

\section{INSTITUTO GEOGRAFIO AGUSTIN CODAZZI}

- IGAC. Mapa de suelos de Colombia.

(Memoria Explicativa). Bogotá: Ministerio de Hacienda y Crédito Público, 1982. 86p.

\section{INSTITUTO GEOGRAFIO AGUSTIN CODAZZI}

- IGAC. Suelos y bosques de

Colombia. Bogotá: Ministerio de Hacienda y Crédito Público, 1988. Mapas: 1, 2, 21, 27 y 37.

KOEHLER, A.; GALVÃO, F.; LONGHI, S.J. Floresta umbrófila densa altomontana: aspectos florísticos e estructuráis de diferentes trechos na Serra do Mar, PR. Ciência Florestal, v. 12, n.2, p. 27-39, 2002.

LEWIS, S.L.; SONKÉ, B.; SUNDERLAND, T.; BEGNE, S.K.; LOPEZ-GONZALEZ, G.; HEIJDEN, G.M.F. VAN DER.; PHILLIPS, O.L.; AFFUMBAFFOE, K.; BAKER, T.R.; BANIN, L.; BASTIN, J.-F.; BEECKMAN, H.; BOECKX, P.; BOGAERT, J.; CANNIÈRE, C.D.; CHEZEAUX, E.; CLARK, C.J.; COLLINS, M.; DJAGBLETEY, G.; DJUIKOUO, M.N.K.; DROISSART, V.; DOUCET, J.-L.; EWANGO, C.E.N.; FAUSET, S.; FELDPAUSCH, T.R.; FOLI, E.G.; GILLET, J.-F.; HAMILTON, A.C.; HARRIS, D.J.; HART, T.B.; HAULLEVILLE, T, DE.; HLADIK, A.;

HUFKENS, K.; HUYGENS, D.; JEANMART, P.; JEFFERY, K.J.; KEARSLEY, E.; LEAL, M.E.; LLOYD, J.; LOVETT, J.C.; MAKANA, J.R.; MALHI, Y.; MARSHALL, A.R.; OJO, L.; PEH, K.S.H.; PICKAVANCE, G.; POULSEN, J.R.; REITSMA, J.M.; SHEIL, D.; SIMO, M.; STEPPE, K.; TAEDOUMG, H.E.; TALBOT, J.; TAPLIN, J.R.D.; TAYLOR, D.; THOMAS, S.C.; TOIRAMBE, B.; VERBEECK, H.; VLEMINCKX, J.; WHITE, L.J.T.; WILLCOCK, S.; WOELL, H.; ZEMAGHO, L. Above-ground biomass and structure of 260 African tropical forests. Philosophical Transactions of the Royal Society B. 368, $20120295,2013$.

LONDOÑO-VEGA, A.C.; ALVAREZ-DÁVILA, E. Composición florística de dos bosques (tierra firme y varzea) en la región de Araracuara, amazonia colombiana. Caldasia, v. 19, n.3, p.431-463, 1997. 
LONDOÑO-VEGA, A.C. Flora and dynamics of an up land and a flood plain forest in Peña Roja, Colombian Amazonia. 2011. (PhD) Universiteit van Amsterdam, 2011.

LÓPEZ, O.R.; KURSAR, T.A. Does flood tolerance explain tree species distribution in tropical seasonally flooded habitats?.

Oecologia v.136, p.193-204, 2003.

MOSQUERA, L.J.; MURILLO, D.R.; ASPRILLA, A. Diversidad florística de dos zonas de bosque tropical húmedo en el municipio de Alto Baudó, Chocó-Colombia. Acta biológica Colombina, v. 12, p.75-90, 2007.

MYERS, N.; MITTERMEIER, R.A.; MITTERMEIER, C.G.; DA FONSECA, G.A.B.; KENT, J. Biodiversity hotspots for conservation priorities. Nature, v.403, p.853-858, 2000.

PARENT, C.; CAPELLI, N.; BERGER, A.; CREVECOUER, M.; DAT, J.F. An overview of plant responses to soil waterlogging. Plant Stress, v.2, n.1, p.20-27, 2008.

PETERS, C.M.; BALICK, M.J.; KAHN, F.; ANDERSON, A.B. Oligarchic forest of economic plants in Amazonia: utilization and conservation of an important tropical resource.

Conservation Biology, v.3, p.341-349, 1989.

PITMAN, N.C.A.; ANDINO, J.E.G.; AULESTIA, M.; CERÓN, C.E.; NEILL, D.A.; PALACIOS, W.; RIVAS-TORRES, G.; SILMAN, M.R.; TERBORGH, J.W. Distribution and abundance of tree species in swamp forests of Amazonian Ecuador. Ecography, v.37, p.902-915, 2014.

PROCTOR, J.; ANDERSON, J.M.; FOGDEN, S.C.L.; VALLACK, H.W. Ecological studies in four contrasting lowland rain forests in Gunung Mulu National Park, Sarawak. Journal of Ecology, v.71, p.261-283, 1983.

QUINTO-MOSQUERA, H.; MORENO-HURTADO, F. Diversidad Florística Arbórea y su Relación con el Suelo en un Bosque Pluvial Tropical del Chocó Biogeográfico. Revista Árvore, v.38, n.6, p.1123-1132, 2014.

RANGEL, J.O. Amenazas a la biota y a los ecosistemas del Chocó biogeográfico. In: RANGEL,
J.O. (Ed). Diversidad biótica IV. Bogotá: Instituto de Ciencias Naturales, Universidad Nacional de Colombia, 2004. p.881-1002.

STEVENSON, P.; CASTELLANOS, M.C.; MEDINA, A.P. Elementos arbóreos de los bosques de un plano inundable en el parque Nacional Natural Tinigua, Colombia. Caldasia, v.21, n.1, p.38-49, 1999

STEVENSON, P.R.; RODRÍGUEZ, M.E.

Determinantes de la Composición Florística y Efecto de Borde en un Fragmento de Bosque en el Guaviare, Amazonia Colombiana. Revista Colombia Forestal. v. 11, p.5-17, 2008.

TILMAN, D.; PACALA, S. The maintenance of species diversity in plant communities. Species diversity in ecological communities. Chicago: University of Chicago Press, 1993. p.13-25.

TUOMISTO, H.; RUOKOLAINEN, K.; KALLIOLA, R.; LINNA, A.; DANJOY, W.; RODRÍGUEZ, Z. Dissecting Amazonian Biodiversity. Science, v.269, p.63-66, 1995.

UHL, C.; MURPHY, P.G. Composition, structure, and regeneration of a tierra firme forest in the Amazon Basin of Venezuela. Tropical Ecology, v.22, n.2, p.219-237, 1981.

URREGO-GIRALDO, L.E. Los bosques inundables del medio Caquetá: caracterización y sucesión. Bogotá: Tropenbos Colombia, 1997. (Serie Tropenbos Colombia, 14).

YEPES-QUINTERO, A.P.; JARAMILLORESTREPO, S.L.; DEL VALLE-ARANGO, J.I.; ORREGO-SUAZA, S.A. Diversity and floristic composition of successional andean forests of the porce region, Colombia. Actualidades Biológicas, v.29, n.86, p.107-117, 2007.

ZANNE, A.E.; LOPEZ-GONZALEZ, G.; COOMES, D.A.; ILIC, J.; JANSEN, S.; LEWIS, S.L.; MILLER, R.B.; SWENSON, N.G.; WIEMANN, M.C.; CHAVE, J. Global wood density database. Dryad. Identifier: http://hdl.handle.net/10255/dryad.235. Excel Libro. 2009.

ZULUAGA, S.R. Observaciones fitoecológicas en el Darién Colombiano. Pérez-Arbelaezia, v.1, p.85-145, 1987.

Revista Árvore, Viçosa-MG, v.40, n.5, p.833-843, 2016 